\title{
Mechanical performance of marine sandwich composites subjected to flatwise compression and flexural loading
}

DOI:

$10.1177 / 1099636218792671$

\section{Document Version}

Accepted author manuscript

Link to publication record in Manchester Research Explorer

\section{Citation for published version (APA):}

Balkolu, F., Demirciolu, T. K., Yldz, M., Arslan, N., \& Ata, A. (2020). Mechanical performance of marine sandwich composites subjected to flatwise compression and flexural loading: Effect of resin pins. Journal of Sandwich Structures and Materials, 22(6), 2030-2048. https://doi.org/10.1177/1099636218792671

\section{Published in:}

Journal of Sandwich Structures and Materials

\section{Citing this paper}

Please note that where the full-text provided on Manchester Research Explorer is the Author Accepted Manuscript or Proof version this may differ from the final Published version. If citing, it is advised that you check and use the publisher's definitive version.

\section{General rights}

Copyright and moral rights for the publications made accessible in the Research Explorer are retained by the authors and/or other copyright owners and it is a condition of accessing publications that users recognise and abide by the legal requirements associated with these rights.

\section{Takedown policy}

If you believe that this document breaches copyright please refer to the University of Manchester's Takedown Procedures [http://man.ac.uk/04Y6Bo] or contact uml.scholarlycommunications@manchester.ac.uk providing relevant details, so we can investigate your claim.

\section{OPEN ACCESS}




\title{
MECHANICAL PERFORMANCE OF MARINE SANDWICH COMPOSITES SUBJECTED TO FLATWISE COMPRESSION AND FLEXURAL LOADING: EFFECT OF RESIN PINS
}

\author{
F. Balıkoğlu ${ }^{1}$, T.K. Demircioğlu ${ }^{1}$, M. Yıldız 2 N. $\operatorname{Arslan}^{3}$, A. Ataş ${ }^{1 *}$
}

\begin{abstract}
Mechanical performance of marine sandwich panels comprising E-glass/vinyl ester face sheets and perforated poly-vinyl chloride (PVC) foam core was evaluated and compared with conventional foam core sandwich panels. Circular holes through the foam core thickness were drilled with twelve different arrangements in square patterns and the holes were filled with the resin during the infusion process which created the through the thickness solid resin pins. The effect of each pattern on the flatwise compression and core shear properties of the sandwich panels were experimentally investigated. The three-point bending maximum failure load of perforated foam core sandwich (PRFCS) panels was increased over $133.8 \%$ by increasing the diameter of the resin pins at the expense of increased panel weight up to $67 \%$. The flatwise compression stress to induce core crushing was significantly increased by reinforcing resin pins.
\end{abstract}

Keywords

Composite sandwich panels, resin pins, bending response, core shear, compression.

\footnotetext{
${ }^{1}$ Department of Mechanical Engineering, Balıkesir University, Balıkesir, 10145, Turkey

${ }^{2}$ Department of Mechanical Engineering, Ankara Y1ldırım Beyazit University, Turkey

${ }^{3}$ Department of Energy Systems Engineering, Manisa Celal Bayar University, Manisa, Turkey
}

* Corresponding author: a.atas@balikesir.edu.tr ( Tel: +90 266 6121194/5106),

Department of Mechanical Engineering, Balikesir University, Balikesir, 10145, Turkey 


\section{Introduction}

Sandwich composites are used in a wide range of applications in aircraft, aerospace, marine and automotive industries mainly because of their great bending resistance, lighter weights, and corrosion resistance ${ }^{1}$. A sandwich structure comprises of two thin, stiff and strong face sheets, which are separated by thick, lightweight and low-strength core materials ${ }^{2}$. The basic concept of a sandwich composite is that the face sheets primarily resist the bending and in-plane loads while the core is effective on the flexural stiffness, out-of-plane shear and compressive behavior. The overall performance of a sandwich structure is determined by the mechanical properties of the face sheets, rigidity of the core, face-to-core bonding characteristics and quality of the manufacturing ${ }^{3,4}$. In marine foam core sandwich (FCS) structures, face sheets are usually composed of glass fiber reinforced polymer (GFRP) or carbon fiber reinforced polymer (CFRP) material systems while balsa wood, closed-cell PVC foam and polyester non-woven core mat fabrics are used as core material ${ }^{5}$.

In modern boat and yacht manufacturing, vacuum-assisted resin transfer molding (VARTM) is commonly used to manufacture large hull and deck components. The VARTM method enables to produce defect free marine sandwich composites with great dimensional stability and high fibre content for maximum specific strength/rigidity and fatigue resistance ${ }^{6}$. In the VARTM method, perforated and grooved foam core configurations have been preferred in practice in order to enhance resin flow across the face-core interface and face fabrics of the marine sandwich structures. However, such perforations increase the weight of the sandwich panel due to increased resin volume, which has a significantly higher density in comparison to the foam core ${ }^{7,8}$. In addition to core modification process, stitching, Z-pinning, and shear key methods have been developed to improve the debonding and delamination resistance of sandwich panels. Recently, through-thickness stitching process was introduced as a methodology of improving the inter-laminar strength of sandwich panels ${ }^{9-12}$. As an alternative, Z-pinning was developed as a through-thickness core reinforcement method to enhance the out-ofplane properties, and delamination strength of the sandwich structures ${ }^{13-16}$. For instance, by reinforcing a sandwich panel with Z-pins, it was reported that the core crushing strength and total absorbed compressive strain energy could be increased up to $600-700 \%$ under flatwise compression tests ${ }^{15}$. A shear-key method was proposed as an alternative methodology to stitching and Z-pinning processes by Mitra N. ${ }^{17}$. This method involves the foam core modification process in which the shear key grooves of different shape, size and orientation are milled on the surface of foam materials. Experimental and numerical results demonstrated the efficiency of introducing the shear keys into the sandwich panels to improve the shear performance compared to the conventional panels $^{17,18}$. Moreover, the delamination initiation load of sandwich composite columns subjected to in-plane compressive loading could be increased approximately $25 \%$ by inserting pre-manufactured shear keys in foam-core grooves ${ }^{19}$. The shear key design was suggested to be more cost effective and commercially available in comparison to Zpinning and stitching methods.

Limited core modification studies have also been performed in order to increase the mechanical performance. May-Pat et al. ${ }^{20}$ studied out-of plane compression, in-plane shear and fracture toughness properties of the sandwich composites composed of E- 
glass/polyester face sheets and PVC foam core with and without perforation. The through-thickness circular perforations of $3.2 \mathrm{~mm}$ average diameter arranged in a $25 \mathrm{~mm}$ square pattern were designed to improve resin flow and bonding between the face skins and the core. It was highlighted that using such core-perforated panels had no advantage on in-plane shear properties, but compression strength was greatly improved with a slight improvement of fracture toughness. However, the specimen weight was increased by $30 \%$. Mechanical properties of the foam core sandwich composites with different hole patterns were investigated by Halimi F. et al. ${ }^{21}$. Hexagonal and square patterns with 2 and $4 \mathrm{~mm}$ diameter holes were drilled on the PVC foam to facilitate the resin flow from one side of the core to the other. Maximum load and energy absorption capacity under flexural tests increased up to $38 \%$ and $100 \%$, respectively. Abdi B. et al. ${ }^{22,23}$ reported the mechanical properties of pin-reinforced foam core sandwich (PRFCS) panels. The hole diameters of polymer pins had a large influence on the flexural, out-of plane compression and indentation behavior of PRFCS panels. The flexural properties of PRFCS panels with a pin diameter of 2 and $3 \mathrm{~mm}$ (PRFCS2 and PRFCS3) were increased by 44.9\% and $48.6 \%$ in maximum value for load/weight compared to the foam core sandwich (FCS) panels, respectively ${ }^{22}$. Moreover, the ultimate compression failure load/weight values of PRFCS2 and PRFCS3 samples were found to be 3.6 and 5.53 times higher than FCS panels ${ }^{23}$.

Although there have been some efforts devoted to investigate the perforated foam core panels, the effect of the perforations as a function of the hole area density is not fully understood. Z-pinning and stitching methods have manufacturing difficulties in marine sandwich constructions and they increase production time and the fabrication cost due to additional preparation and processing required. Furthermore, when Z-pinning and stitching processes are performed through the layers of face sheets, the load bearing fibers are distorted and the plies are damaged while introducing the pins or yarn to the face sheets. Therefore, initial damage may induce in the structure which reduces the mechanical performance of the laminates ${ }^{9,}{ }^{13}$. It should also be noted that perforated core materials may be used in conjunction with the shear key, and stitching methods. For instance, Yalkin H.E et al. ${ }^{24,}{ }^{25}$, used the perforated-stitched foam core to ensure performance improvement for the sandwich composites. Authors reported that stitching the foam core can be a difficult procedure for composite manufacturers, so stitched-foam products need to be launched as a new product from suppliers. However, the perforated and grooved core configurations are commercially available and can be used in boat/yacht building without the need of any additional operations. The large composite parts such as boat hull and deck may be constructed "in one go" by the VARTM method.

In the present work, the main objective is to study the mechanical performance of marine sandwich panels composed of perforated PVC foam core and E-glass/vinyl ester laminates with two different stacking sequences. In the construction of hulls, the thick face sheet is placed as the outer side and bears the loads and covered by a foam core reducing the vibration and noise on board, while the thin one is placed as the inner side and eases the junction with the other components of the boat ${ }^{26,27}$. The effect of various square perforation patterns on the flexural, and flatwise compression behavior of the PRFCS panels was investigated experimentally. The flexural and compression properties 
and strength of the PRFCS samples have been presented in comparison with nonperforated control sample.

\section{Material and methods}

Sandwich samples were composed of E-glass fiber/vinyl ester face sheets and closed cell PVC foam core material. The $25 \mathrm{~mm}$ thick core material has a density of $80 \mathrm{~kg} / \mathrm{m}^{3}$, manufactured by Airex AG Inc. and marketed by the trade name of Airex C70.75. The holes extending through-the-thickness of the PVC foams were drilled by a CNC machine in a square arrangement. Then, the holes were cleaned by compressed air to remove the dust and other particles. These through-thickness perforations help the resin flow during the infusion process and the resin in these holes formed the solid pins when the panel is completely cured as seen in Fig 1a. The face material system consists of E-glass noncrimp biaxial fabrics and E-glass mats with an $850 \mathrm{gr} / \mathrm{m}^{2}$ and $450 \mathrm{gr} / \mathrm{m}^{2}$ areal weights, respectively. The stacking sequences and thicknesses of upper and lower face-sheets are given in Table 1 The effective mechanical properties of face -sheets (in warp direction of fabrics and in the longitudinal direction of panel) of the sandwich panel were determined from testing of coupon specimens following the ISO and ASTM test standards ${ }^{28-31}$ and are listed in Table 2. PVC foam properties were obtained from data sheets (Table 3). Sandwich panels were fabricated using vacuum assisted resin transfer molding (VARTM) method with bisphenol-A epoxy vinyl ester resin. The samples were cured at room temperature for $24 \mathrm{~h}$. The side dimensions of the perforated PVC foams with 4,6 and 8 $\mathrm{mm}$ holes are 12,14,16,18 $\mathrm{mm}$ as illustrated in Fig 1b. Here, a side dimension of a square pattern represents the distance between the centers of the holes. The sandwich panels will be hereafter designated with the hole diameter and the side dimensions (s). For instance, Ø4-s12 represents the perforated panel with a $4 \mathrm{~mm}$ hole diameter and a 12 $\mathrm{mm}$ side dimension. The specific sandwich panel configuration, used to manufacture boat hulls, was unsymmetrical as illustrated in Fig. 1c.

\section{[insert Figure 1.]}

Table1. The Stacking sequences of upper and lower face-sheets

\begin{tabular}{|c|c|c|c|c|}
\hline Face sheets & Thickness & Order of Lamina & Distribution of fibers & Unit mass $\left(\mathrm{kg} / \mathrm{m}^{2}\right)$ \\
\hline \multirow{6}{*}{$\begin{array}{c}\text { Upper } \\
\text { Face sheet }\end{array}$} & \multirow{6}{*}{$4 \mathrm{~mm}$} & 1 & Randomly/Mat & 0.45 \\
\hline & & 2 & Randomly/Mat & 0.45 \\
\hline & & 3 & Biaxial 0/90 fabric & 0.85 \\
\hline & & 4 & Biaxial 0/90 fabric & 0.85 \\
\hline & & 5 & Biaxial 0/90 fabric & 0.85 \\
\hline & & 6 & Biaxial 0/90 fabric & 0.85 \\
\hline \multirow{3}{*}{$\begin{array}{c}\text { Lower } \\
\text { Face sheet }\end{array}$} & \multirow{3}{*}{$2.4 \mathrm{~mm}$} & 1 & Biaxial 0/90 fabric & 0.85 \\
\hline & & 2 & Biaxial 0/90 fabric & 0.85 \\
\hline & & 3 & Biaxial 0/90 fabric & 0.85 \\
\hline
\end{tabular}


Table 2. Mechanical properties of upper and lower face sheets of the marine sandwich panel

\begin{tabular}{ccccc}
\hline Test & & Property & Upper Face sheet & Lower Face sheet \\
\hline \multirow{2}{*}{ Flexural } & \multirow{2}{*}{ ISO 14125 } & Modulus (GPa) & 14.77 & 12.19 \\
\cline { 3 - 5 } & & Strength (MPa) & 431.38 & 378.75 \\
\hline \multirow{2}{*}{ Tensile } & \multirow{2}{*}{ ISO 527-1 $^{29}$} & Modulus (GPa) & 22.49 & 20.69 \\
\cline { 3 - 5 } & & Strength (MPa) & 394.13 & 355.92 \\
\cline { 3 - 5 } Compression & \multirow{2}{*}{ ASTM D6641 } & Poisson ratio & 0.17 & 0.143 \\
\hline \multirow{2}{*}{ Shear } & \multirow{2}{*}{ ASTM D7078 } & Strength (MPa) & 244.18 & 226.67 \\
\cline { 3 - 5 } & & Modulus (GPa) & 4.37 & 4.07 \\
\cline { 3 - 5 } & & Strength (MPa) & 53.5 & 51.6 \\
\hline
\end{tabular}

Table 3. Mechanical properties of PVC foam (see in Airex C.70.75 PVC foam data sheet)

\begin{tabular}{ccc}
\hline Test & Property & Value \\
\hline \multirow{2}{*}{ Tension } & Modulus (MPa) & 66 \\
\cline { 2 - 3 } & Strength (MPa) & 2 \\
\hline \multirow{2}{*}{ Compression } & Modulus (MPa) & 104 \\
\cline { 2 - 3 } & Strength (MPa) & 1.45 \\
\hline \multirow{3}{*}{ Shear } & Modulus $(\mathrm{MPa})$ & 30 \\
\cline { 2 - 3 } & Strength $(\mathrm{MPa})$ & 1.2 \\
\cline { 2 - 3 } & Shear Elongation at break $(\%)$ & 23 \\
\hline
\end{tabular}

\section{Experimental study}

\section{Three-point bending tests}

Three-point bending tests of PRFCS samples were performed in accordance with the ASTM C393/C393M-16 standard in order to determine the flexural properties ${ }^{32}$. The length of the support span was equal to $200 \mathrm{~mm}$. A Zwick Roell Z250 test machine with a $250 \mathrm{kN}$ load cell was used to load the samples at a constant crosshead speed of 6 $\mathrm{mm} / \mathrm{min}$. Due to the unsymmetrical nature of the face sheets, flexural down (the thicker face sheet is at bottom surface) and flexural up (the thicker face sheet is on top surface) loading were performed, as shown schematically in Fig. 2. This test typology was previously used by Di Bella G.et $\mathrm{al}^{33}$. Di Bella et al. used such an unsymmetrical laminate to realize the cover exhaust part of a boat. The dimensions of the sandwich beam based on the test configuration ${ }^{32}$ for the three-point bending tests are $250 \mathrm{~mm} \times 90$ $\mathrm{mm}$. Both the failure loads and failure type of the PRFCS samples were recorded and compared with the FCS control sample. For each type of sample, at least three tests were conducted to ensure the repeatability of the bending test results.

[insert Figure 2.] 


\section{Flatwise compression tests}

Flatwise compression tests were performed according to the ASTM C365/C365M-0 $05^{34}$. The compressive strength and modulus of the PRFCS samples were investigated in comparison to those of FCS samples. Figure 3 presents the schematic view of the flatwise compression test fixture. Tests were performed at a displacement rate of $0.5 \mathrm{~mm} / \mathrm{min}$. The dimensions of the test samples were $80 \mathrm{~mm} \times 80 \mathrm{~mm}$. Flatwise compression tests of selected PRFCS samples (Ø4-s12, Ø4-s16, Ø6-s14, Ø6-s16, Ø8-s12 and FCS control sample) were performed to observe the enhancement in the core crushing strength with the presence of the perforations. The test for each sample was repeated at least three times to make sure the repeatability of the compression test results.

[insert Figure 3.]

\section{Results and discussions}

\section{Flexural test results}

Load versus cross-head displacement curves of the PRFCS and FCS samples under flexural tests are shown in Figs. 4-8. The failure load, deflection at failure load, increase in failure load and damage modes of PRFCS and FCS samples are compared and listed in Table 4. The three-point bending test results of FCS samples are illustrated in Figure 4. Deflection at failure load and maximum load of the FCS sample in flexural up loading are higher due to the presence of the thicker skin in the upper side (Table 4). This results in a higher resistance of the FCS sample to local buckling. These samples failed due to the local buckling of the top face sheet under both loading types.

[insert Figure 4.]

The flexural down test results of the PRFCS samples with $\varnothing 4, \varnothing 6$ and $\varnothing 8 \mathrm{~mm}$ hole diameters with 12, 14, 16 and $18 \mathrm{~mm}$ side edge dimensions are shown in Figs.5-7. Perforated samples with the largest diameter $(\varnothing 8 \mathrm{~mm})$ have the highest load carrying capacity under bending. Approximately $134 \%$ increase was observed in the bending failure load of Ø8-s18 samples in comparison to the FCS sample. Moreover, nonperforated FCS sample and Ø8-s18 samples failed under $4.573 \mathrm{~mm}$ and $10.057 \mathrm{~mm}$ deflection, respectively (Table 4). The pins increased the flexural stiffness and maximum load carrying capacity of the sandwich panels. It is clear that increased resin pin diameter increased the failure load of the PRFCS panels under three-point bending test. Because, increased resin pin diameter reduced the volume of the relatively softer PVC foam and improved the shear properties of the PRFCS panels. The pins stiffens and strengthens the PVC foam against failure at low shear loads while the foam core supports the pins and keeps them from collapsing under the effect of a shear force.

Experimental results showed that PRFCS panels showed different failure mechanisms in the flexural down tests. Figures $8 \mathrm{a}, \mathrm{b}$ and $\mathrm{c}$ show the failure mode of PRFCS samples subjected to the flexural down loading. Ø4-s18 samples failed due to local face sheet buckling along the loading line and no failure was observed in the foam core. The resin pins were buckled and the upper face sheet was failed at the contact location of crosshead and face sheet in these samples. Ø4-s14 and Ø6-s18 samples showed both upper skin buckling and core shear failure. Other PRFCS samples collapsed due to core shear 
damage. The deviations in the maximum loads and deflections at failure loads of the sandwich samples are related to their failure mechanisms. As can be seen from Table 4, for instance Ø4-s14 sample showed a lower failure load at around similar deflection in comparison with Ø4-s12 sample due to their damage type differences. The same result can be observed in the Ø6-s16 and Ø6-s18 sandwich panels. For the Ø4-s14 and Ø6-s18 samples, the load versus cross-head displacement curves showed oscillations in loading portion before core failure as seen in Figs. $5 \mathrm{~b}$ and $6 \mathrm{~d}$. These oscillations are attributed to the failure of upper face sheet. Ø4-s12 and Ø6-s12 samples showed linear behavior up to the initiation of the first shear crack in the foam core. This was followed by a non-linear behavior due to cracking of the foam core which decreased the stiffness of the panels as well as rupture of the resin pins (see Figs 5a and 6a). However, Ø8-s12 samples initially showed a slight drop in the load and then a large plateau-like region after the peak load. This plateau was related to the crack propagation between the bottom face sheet and the foam core. There was an increased amount of deflection even without an increase in the applied load as illustrated in Fig. 7a. The resin pins continued to carry the load without being damaged until debonding was completed. Ø8-s14, Ø8-s16 and Ø8-s18 samples exhibited a bi-linear behavior (Figs.7 b, c d). This was likely due to the resistance of the resin pins to inclination under the bending loads. A similar behavior was reported by Wang B. et $\mathrm{al}^{35}$. However, rupture of the resin pins due to shear loads was not observed in these samples (Fig. 8c). This result indicated that the value of compression force of crosshead to generate shear cracking of the $8 \mathrm{~mm}$ resin pins is higher than the core shear strength of foam material.

[insert Figure 5, 6, 7]

The flexural up test results of the PRFCS samples with $\varnothing 4$ and $\varnothing 8 \mathrm{~mm}$ hole diameters with 12 and $16 \mathrm{~mm}$ side edge dimensions are shown in Figs. 9 a-d. These selected PRFCS samples were tested to determine any improvement under flexural up loading condition. Figure 8d shows the failure modes of sandwich panels tested under flexural-up loading. Ø4-s12 and Ø4-s16 samples were damaged due to shear failure of foam core (Fig. 8d). These samples showed a nonlinear response until failure as seen in Figs 8 a, b. Ø8-s12 and Ø8-s16 samples exhibited similar behavior in the curves when compared with those subjected to the flexural down loading. Core shear damage with more brittle manner was observed in all PRFCS samples tested in the flexural up position. This is shown by low deflection value at failure load as seen in Table 4 . The upper skin damage causing a poor load transfer capability between the sandwich constituents was not observed in flexural up tests ${ }^{26}$.

[insert Figure 8.]

[insert Figure 9.]

It can be concluded that the resin filled holes act as pins joining upper and lower face sheets to the PVC foam and so the applied load can be transferred to the bottom face sheet via the hole filled with vinyl-ester resin in the foam. It is known that shear strength of the core is one of the most important mechanical properties and is critical parameter when designing composite sandwich structures ${ }^{36}$. These pins provide resistance to the shear force and improve the load-bearing properties of the PRFCS samples. Moreover, when comparing the initial flexural stiffness from the load-displacement curves of PRFCS samples; stiffer panels were obtained with increasing the diameter of holes. The hole diameter had a considerable effect on the core shear failure loads. Also, the 
deflection at failure load increased with increasing the distance between the holes for both loading types. However, core modification on the PVC foam increased the specimen weight due to filling the holes with resin. The amount of change in weight of PRFCS samples with different square hole patterns is given and compared to FCS sample in weight gain section.

Table 4. Comparison of PRFCS and FCS panels subjected to three-point flexural loading

\begin{tabular}{|c|c|c|c|c|c|c|}
\hline Loading & $\begin{array}{c}\text { Pin } \\
\text { diameter } \\
(\mathrm{mm})\end{array}$ & Sample & $\begin{array}{c}\text { Failure } \\
\text { load } \\
(\mathrm{N}) \\
\end{array}$ & $\begin{array}{l}\text { Deflection } \\
\text { at failure load }(\mathrm{mm})\end{array}$ & $\begin{array}{c}\text { Increase in } \\
\text { failure load \% }\end{array}$ & $\begin{array}{l}\text { Damage } \\
\text { mode }\end{array}$ \\
\hline \multirow{13}{*}{ 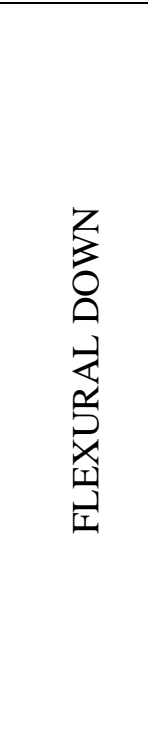 } & \multirow{4}{*}{ 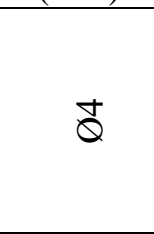 } & Ø4-s12 & 6760 & 7.486 & 70.1 & $\mathrm{CS}$ \\
\hline & & Ø4-s14 & 5905 & 7.438 & 48.6 & UFB-CS \\
\hline & & Ø4-s16 & 7383 & 9.507 & 85.8 & $\mathrm{CS}$ \\
\hline & & Ø4-s18 & 4468 & 4.651 & 12.5 & UFB-CC \\
\hline & \multirow{4}{*}{ இ } & Ø6-s12 & 7070 & 5.478 & 48.1 & $\mathrm{CS}$ \\
\hline & & Ø6-s14 & 7888 & 6.946 & 98.5 & $\mathrm{CS}$ \\
\hline & & Ø6-s16 & 7734 & 9.389 & 94.7 & $\mathrm{CS}$ \\
\hline & & Ø6-s18 & 6624 & 9.321 & 66.7 & UFB-CS \\
\hline & \multirow{5}{*}{$\stackrel{\infty}{Q}$} & Ø8-s12 & 7409 & 7.312 & 86.5 & $\mathrm{CS}$ \\
\hline & & Ø8-s14 & 8786 & 8.842 & 121.1 & CS \\
\hline & & Ø8-s16 & 7855 & 10.040 & 97.7 & $\mathrm{CS}$ \\
\hline & & Ø8-s18 & 9289 & 10.057 & 133.8 & $\mathrm{CS}$ \\
\hline & & FCS & 3973 & 4.573 & - & UFB \\
\hline \multirow{5}{*}{ 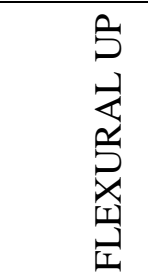 } & \multirow{2}{*}{$\ddot{Q}$} & Ø4-s12 & 7259 & 6.454 & 40.7 & $\mathrm{CS}$ \\
\hline & & Ø4-s16 & 7115 & 7.455 & 37.9 & $\mathrm{CS}$ \\
\hline & \multirow{3}{*}{$\stackrel{\infty}{Q}$} & Ø8-s12 & 7972 & 7.088 & 54.6 & $\mathrm{CS}$ \\
\hline & & Ø8-s16 & 8516 & 8.137 & 65.1 & $\mathrm{CS}$ \\
\hline & & FCS & 5158 & 7.169 & - & UFB \\
\hline
\end{tabular}

- CS: Core Shear, UFB: Upper Face sheet Buckling, CC: Core Crushing

\section{Flatwise compression test results}

Figures 10 a-f show that the flatwise compression behavior of PRFCS and FCS samples are considerably different. The failure modes of PRFCS samples under compression loading are given in Fig. 11. The compression properties of PRFCS panels are higher than the FCS control panel as shown in Table 5. The difference is due to the compression properties of the resin pins being higher than the PVC foam core alone. The compressive strength and modulus are increased by increasing the quantity of the resin pins in the foam core. The cured resin pins significantly increased the foam crushing resistance under compression load. For instance, an increase of about $570 \%$ was achieved in the compressive failure load of Ø8-s12 sample compared to the FCS sample (Table 5). For the FCS control/reference sample, the foam carries the compressive load alone and when the compressive load reaches the maximum value, a large plateau region is 
observed in the load-displacement curve (Fig.10f). Furthermore, FCS reference sample collapsed at 1.4 MPa stress level, which is the same value of compressive strength of pure PVC foam ${ }^{20}$. However, the compressive loads of PRFCS samples are mainly carried by the resin pins. Load-displacement curves of Ø4-s12, 16, Ø6-s14, 16, samples increases linearly up to yielding and then keep increasing non-linearly up to the maximum load (see Figs. 10 a-d). Thereafter, load decreases smoothly with increasing deflection. This yielding point corresponds to the crushing failure of resin pins under compression loading. Beyond this point, the pins were subjected to permanent damage by being buckled up to failure. For $\varnothing 4-s 12$ and $\varnothing 4-s 16$ samples, the pins were broken following the buckling as seen in Figs. 11 and b, whereas Ø6-s14 and Ø6-s16 samples experienced some inclination before the damage of the pins (see Figs. $11 \mathrm{c}$ and d).

It is clear from Fig. 10 that there is no obvious yield point in Ø8-s12 samples, which show a non-linear behavior up to maximum load. In this regime, resin pins with a $8 \mathrm{~mm}$ diameter experience a plastic deformation. As seen in Fig. 11 e, Ø8-s12 sample showed the largest pin inclination among others and then was exposed to buckling and crushing at the contact region between the face sheet and the resin pins. When the results are examined, the stronger pins experience a larger angle of inclination against the face sheets up to failure. As expected, this result indicates that pins with larger diameters are more resistant to buckling. Compression test results also showed that the increased side length (s) of the square pattern of perforations decreased the compressive strength and rigidity of the test samples.

[insert Figure 10.]

[insert Figure 11.]

Table 5. Flatwise Compression Test Results

\begin{tabular}{ccccccc}
\hline $\begin{array}{c}\text { Flatwise Compression Test } \\
\text { Results }\end{array}$ & $\varnothing 4-\mathrm{s} 12$ & $\varnothing 4-\mathrm{s} 16$ & $\varnothing 6-\mathrm{s} 14$ & $\varnothing 6-\mathrm{s} 16$ & $\varnothing 8-\mathrm{s} 12$ & FCS \\
\hline Elastic modulus (MPa) & 187.7 & 105.8 & 207.7 & 174.9 & 270.7 & 76.5 \\
\hline Max. load (kN) & 26.7 & 18.3 & 56.0 & 59.9 & 75.7 & 11.3 \\
\hline Stress at max. load (MPa) & 7.0 & 2.9 & 10.2 & 9.4 & 15.7 & 1.4 \\
\hline Deflection at max. load (mm) & 4.6 & 5.9 & 3.6 & 4.3 & 3.9 & 5.0 \\
\hline
\end{tabular}

Weight gain

It is important to justify the use of resin pins for increasing the mechanical performance of the sandwich samples despite the weight penalty. For establishing the weight gain of the PRFCS samples due to resin filling of the core perforations, sandwich panel sections of $250 \mathrm{~mm} \times 500 \mathrm{~mm}$ were weighted after the resin infusion process. The theoretical weights of the PRFCS panels were predicted based on densities and volumes of the resin, foam core and face sheet materials ${ }^{20}$. The measured and theoretical weight ratios of PRFCS to FCS samples are illustrated in Figs. 12a and 12b. As expected, the sample weight ratio (PRFCS/FCS) is increased with increasing the hole diameter and decreasing the distance between the holes. The difference between the theoretical calculations and 
the measurements is minor. It shows that the core perforations are almost completely filled with the vinyl ester resin. Table 6 shows the area fraction of hole (\%), increase in weight (\%) and PRFCS/FCS weight ratio of the samples. By utilizing perforated core with more dense area fraction of the holes, it was aimed to prevent the formation of "resin starved" areas, strengthen foam core to crushing and improve bearing capacity of the sandwich samples. The minimum and maximum weight gains with respect to FCS reference sample are 3.1\% (Ø4-s18) and 67.4\% (Ø8-s12) respectively. Furthermore, specific bending and compression failure loads ratios of PRFCS and FCS samples $\left(\frac{P_{P R F C S}}{W_{P R F C S}} / \frac{P_{F C S}}{W_{F C S}}\right)$ are illustrated in Fig. 12c and 12d. All samples yield more increase in maximum bending loads than their weights. It was also observed that the specific compressive loads of the tested PRFCS specimens were at least 1.5 times and at most 4 times greater than the FCS sample. Therefore, the weight gain can be tolerated in critical applications where increased bending and compression properties are required.

[insert Figure 12.]

Table 6. Comparison of weight measurements of PRFCS and FCS samples

\begin{tabular}{|c|c|c|c|}
\hline Samples & $\begin{array}{c}\text { Area fraction } \\
\text { of the holes }\end{array}$ & $\begin{array}{c}\text { Increase } \\
\text { in weight }(\%)\end{array}$ & $\begin{array}{l}\text { PRFCS/FCS } \\
\text { weight ratio }\end{array}$ \\
\hline Ø4-s12 & 0.151 & 22.1 & 1.221 \\
\hline$\varnothing 4-s 14$ & 0.136 & 7.7 & 1.077 \\
\hline Ø4-s16 & 0.094 & 3.6 & 1.036 \\
\hline Ø4-s18 & 0.075 & 3.1 & 1.031 \\
\hline Ø6-s12 & 0.339 & 34.5 & 1.345 \\
\hline Ø6-s14 & 0.305 & 31.9 & 1.319 \\
\hline Ø6-s16 & 0.212 & 27.1 & 1.271 \\
\hline Ø6-s18 & 0.17 & 25.2 & 1.252 \\
\hline Ø8-s12 & 0.603 & 67.4 & 1.674 \\
\hline Ø8-s14 & 0.543 & 60.2 & 1.602 \\
\hline Ø8-s16 & 0.377 & 43.4 & 1.434 \\
\hline Ø8-s18 & 0.302 & 38.1 & 1.381 \\
\hline
\end{tabular}

\section{Conclusions}

This paper presents an experimental study on the three-point bending, and out of plane compression of the perforated PVC foam core marine sandwich panels. The marine sandwich composites with perforated PVC foam exhibit a significant improvement in the bending load carrying capability and out of plane compressive strength. The resin pins rigidly connect the top and bottom face sheets to the PVC foam. It is seen that failure 
loads and damage modes of PRFCS panels in the three-point bending test depend on the resin pin diameter, distance between the centers of resin pins and the direction of the loading with respect to thicker and thinner face sheets. As expected, the highest improvement was obtained in flatwise compression loading. Solid pins improved the compression elastic modulus and the crush strength. By increasing the diameter of the cured resin pins, the maximum bending and compression failure loads of PRFCS panels were increased. As expected, the weight of the PRFCS panels increased, and so the strength to weight ratios of each ones was compared to FCS control sample. Considering the specific failure load ratios of the PRFCS and FCS samples, all samples showed more increase in compressive and bending strengths than their weights. This result revealed that the foam cores with more dense area fraction of the holes can be used in the design of marine sandwich composites when further load carrying capacity and core crushing resistance are required. Also, the foam core products can be easily drilled and machined by core manufacturers and such perforated foams can be employed by boat and yacht manufacturers without extra preparation and processing costs. This makes the use of perforated foam cores a simpler and a feasible method to achieve the desired performance in marine applications.

\section{Declaration of Conflicting Interests}

The author(s) declared no potential conflicts of interest with respect to the research, authorship, and/or publication of this article.

\section{Funding}

This author(s) received no financial support for the research, authorship, and/or publication from any funding agency in the public, commercial, or not-for-profit sectors.

\section{References}

1. Vinson JR. Sandwich structures. Applied Mechanics Reviews 2001; 54: 201-214.

2. ASTM C274-99,ASTM standard terminology of structural sandwich constructions.

3. Daniel I, Gdoutos E, Wang KA, et al. Failure modes of composite sandwich beams. International Journal of Damage Mechanics 2002; 11: 309-334.

4. Daniel IM, Gdoutos EE, Abot JL, et al. Deformation and failure of composite sandwich structures. Journal of Thermoplastic Composite Materials 2003; 16: 345-364. 
5. Karlsson KF and TomasÅström B. Manufacturing and applications of structural sandwich components. Composites Part A: Applied Science and Manufacturing 1997; 28: 97-111.

6. Dai $\mathrm{J}$ and Hahn HT. Flexural behavior of sandwich beams fabricated by vacuum-assisted resin transfer molding. Composite Structures 2003; 61: 247-253.

7. Truxel A, Aviles F, Carlsson L, et al. Influence of face/core interface on debond toughness of foam and balsa cored sandwich. Journal of Sandwich Structures \& Materials 2006; 8: 237-258.

8. Petrescue L, Hubert P, Gordon S, et al. Characterization of defects in low-cost resin-infused aeronautical structures. In: The 5th Canadian International Composites Conference (CICC) 2005, pp.492-495.

9. Mouritz A, Leong K and Herszberg I. A review of the effect of stitching on the in-plane mechanical properties of fibrereinforced polymer composites. Composites Part A: applied science and manufacturing 1997; 28: 979-991.

10. Lascoup B, Aboura Z, Khellil K, et al. On the mechanical effect of stitch addition in sandwich panel. Composites Science and Technology 2006; 66: 1385-1398.

11. Lascoup B, Aboura Z, Khellil K, et al. Core-skin interfacial toughness of stitched sandwich structure. Composites Part B: Engineering 2014; 67: 363-370.

12. Riccio A, Linde P, Raimondo A, et al. On the use of selective stitching in stiffened composite panels to prevent skin-stringer debonding. Composites Part B: Engineering 2017; 124: 64-75.

13. Mouritz A. Review of z-pinned composite laminates. Composites Part A: applied science and manufacturing 2007; 38: 2383-2397.

14. Mouritz A. Compression properties of z-pinned sandwich composites. Journal of materials science 2006; 41: 5771-5774.

15. Nanayakkara A, Feih S and Mouritz A. Experimental analysis of the through-thickness compression properties of zpinned sandwich composites. Composites Part A: Applied Science and Manufacturing 2011; 42: 1673-1680. 
16. Koh $\mathrm{T}$, Isa $\mathrm{M}$, Feih $\mathrm{S}$, et al. Experimental assessment of the damage tolerance of z-pinned T-stiffened composite panels. Composites Part B: Engineering 2013; 44: 620-627.

17. Mitra N. A methodology for improving shear performance of marine grade sandwich composites: sandwich composite panel with shear key. Composite Structures 2010; 92: 1065-1072.

18. Mostafa A, Shankar K and Morozov E. In-plane shear behaviour of composite sandwich panel incorporated with shear keys methodology at different orientations: finite element study. Journal of Composite Materials 2014; 48: 2945-2959.

19. Mitra N and Raja B. Improving delamination resistance capacity of sandwich composite columns with initial face/core debond. Composites Part B: Engineering 2012; 43: 1604-1612.

20. May-Pat A, Aviles F and Aguilar J. Mechanical properties of sandwich panels with perforated foam cores. Journal of Sandwich Structures \& Materials 2011; 13: 427-444.

21. Halimi F, Golzar M, Asadi P, et al. Core modifications of sandwich panels fabricated by vacuum-assisted resin transfer molding. Journal of Composite Materials 2013; 47: 1853-1863.

22. Abdi B, Azwan S, Abdullah M, et al. Flatwise compression and flexural behavior of foam core and polymer pin-reinforced foam core composite sandwich panels. International journal of mechanical sciences 2014; 88: 138-144.

23. Abdi B, Azwan S, Abdullah M, et al. Comparison of foam core sandwich panel and through-thickness polymer pin-reinforced foam core sandwich panel subject to indentation and flatwise compression loadings. Polymer Composites 2016; 37: 612-619.

24. Yalkin HE, Icten BM and Alpyildiz T. Enhanced mechanical performance of foam core sandwich composites with through the thickness reinforced core. Composites Part B: Engineering 2015; 79: 383-391.

25. Yalkin HE, Icten BM and Alpyildiz T. Tensile and compressive performances of foam core sandwich composites with various core modifications. Journal of Sandwich Structures \& Materials 2017; 19: 49-65. 
26. Di Bella G, Borsellino $\mathrm{C}$ and Calabrese L. Effects of manufacturing procedure on unsymmetrical sandwich structures under static load conditions. Materials \& Design 2012; 35: 457466.

27. Toygar ME, Tee KF, Maleki FK, et al. Experimental, analytical and numerical study of mechanical properties and fracture energy for composite sandwich beams. Journal of Sandwich Structures \& Materials 2017: 1099636217710003.

28. International Standard, ISO 14125, Fibre-reinforced plastic composites - determination of flexural properties.

29. International Standard. Plastics - ISO 527-1-determination of tensile properties - part 1: general principles.

30. ASTM D6641 / D6641M, Standard Test Method for Compressive Properties of Polymer Matrix Composite Materials Using a Combined Loading Compression (CLC) Test Fixture.

31. ASTM D7078 / D7078M, Standard Test Method for Shear Properties of Composite Materials by V-Notched Rail Shear Method.

32. ASTM C393 / C393M-16, Standard Test Method for Core Shear Properties of Sandwich Constructions by Beam Flexure.

33. Di Bella G, Calabrese L and Borsellino C. Mechanical characterisation of a glass/polyester sandwich structure for marine applications. Materials \& Design 2012; 42: 486-494.

34. ASTM C365 / C365M-05, Standard Test Method for Flatwise Compressive Properties of Sandwich Cores.

35. Wang B, Wu L, Jin X, et al. Experimental investigation of 3D sandwich structure with core reinforced by composite columns. Materials \& Design 2010; 31: 158-165.

36. Manalo A. Behaviour of fibre composite sandwich structures under short and asymmetrical beam shear tests. Composite structures 2013; 99: 339-349. 
Figure 1. a. Schematic of PRFCS sandwich panel, b. Square hole patterns, c. Stacking sequence of marine sandwich composite

Figure 2. Schematic view of three-point bending test fixture

Figure 3. Schematic view of flatwise compression test fixture

Figure 4. Load-displacement curves of FCS sample under flexural down and flexural up tests

Figure 5. Load-displacement curves of PRFCS samples with $4 \mathrm{~mm}$ hole diameter under flexural down loading

Figure 6. Load-displacement curves of PRFCS samples with $6 \mathrm{~mm}$ hole diameter under flexural down loading

Figure 7. Load-displacement curves of PRFCS samples with $8 \mathrm{~mm}$ hole diameter under flexural down loading

Figure 8. Cross-sectional damage views of PRFCS samples after flexural down and flexural up tests

Figure 9. Load-displacement curves of Ø4, 8-s12, Ø4, 8-s16 PRFCS samples under flexural up loading

Figure 10. Load-displacement curves of PRFCS and FCS samples under flatwise compression loading

Figure 11. Cross-sectional damage views of PRFCS samples after flatwise compression tests

Figure 12. a, b. Weight measurements and Theoretical predictions for the weight of the sandwich samples, c. Specific bending failure load ratios of PRFCS and FCS samples, d. Specific compression failure load ratios of PRFCS and FCS samples 